\title{
Curcumin Delays Retinal Degeneration by Regulating Microglia Activation in the Retina of rd1 Mice
}

\author{
Yanhe Wanga, b, $\quad$ Zhiyuan Yin ${ }^{a, b} \quad$ Lixiong Gao ${ }^{a, b}$ Dayu Sun ${ }^{a, b} \quad$ Xisu Hua, \\ Langyue Xue ${ }^{a, b}$ Jiaman Daja, ${ }^{a}$ YuXiao Zenga, ${ }^{a, b}$ Siyu Chen ${ }^{a, b} \quad$ Boju Pan ${ }^{a, b}$ \\ Min Chen ${ }^{a, b}$ Jing Xie ${ }^{a, b} \quad$ Haiwei $X u^{a, b}$
}

a,Southwest Hospital/Southwest Eye Hospital, Third Military Medical University, Chongqing; ${ }^{b}$ Key Lab of Visual Damage and Regeneration \& Restoration of Chongqing, Chongqing; 'The Battalion 13 of Cadet Brigade, Third Military Medical University, Chongqing, China

\section{Key Words}

Retinitis pigmentosa $\cdot$ Curcumin $•$ Microglia $\bullet$ rd1 mice $\bullet$ Visual function

\begin{abstract}
Background/Aims: Retinitis pigmentosa (RP) is characterized by degeneration of photoreceptors, and there are currently no effective treatments for this disease. However, curcumin has shown neuroprotectant efficacy in a RP rat and swine model, and thus, may have neuroprotective effects in this disease. Methods: Immunofluorescence staining, electroretinogram recordings, and behavioral tests were used to analyze the effects of curcumin and the underlying mechanism in retinal degeneration $1(\mathrm{rd} 1)$ mice. Results: The number of apoptotic cells in the retina of rd1 mice at postnatal day 14 significantly decreased with curcumin treatment and visual function was improved. The activation of microglia and secretion of chemokines and matrix metalloproteinases in the retina were inhibited by curcumin. These effects were also observed in a co-culture of BV2 microglial cells and retinaderived $661 \mathrm{~W}$ cells. Conclusions: Curcumin delayed retinal degeneration by suppressing microglia activation in the retina of $\mathrm{rd} 1$ mice. Thus, it may be an effective treatment for neurodegenerative disorders such as RP.

(C) 2017 The Author(s)

Published by S. Karger AG, Basel
\end{abstract}

\section{Introduction}

As one of the main causes of blindness, retinitis pigmentosa (RP) is characterized by the degeneration and apoptosis of photoreceptors and retinal pigment epithelium [1]. As of May 23, 2017, more than 67 genes had been identified as pathogenic genes of RP (RetNet, http:// www.sph.uth.tmc.edu/RetNet/). However, to date, there are no effective treatments for this disease.

Haiwei Xu KARGER
Southwest Hospital/Southwest Eye Hospital

Third Military Medical University, Chongqing, (China)

Tel. +86-023-68754803, Fax +86-023-68754401, E-Mail haiweixu2001@163.com 
Microglia, the resident macrophages of the central nervous system, perform tissue surveillance functions in the retina, phagocytosing cellular debris, producing antiinflammatory neuroprotective factors, and presenting antigens [2-4]. During the development of retinal degeneration, microglia are activated by retinal inflammation, which changes their ramified shape into a round-shaped morphology. These activated microglia, known as amoeboid microglia, migrate from the inner to outer retina and phagocytose the debris of degenerated photoreceptors. Activated microglia also produce pro-inflammatory cytokines, which increase the levels of extracellular reactive oxygen species, resulting in neurotoxicity to photoreceptors and other neurons in the retina [3]. It was shown that the tetracycline antibiotic minocycline could suppress microglial activation by decreasing the apoptosis of photoreceptors in the degenerated retina [5]. Chemokines also play an important role in the pathology of RP[6]. In particular, chemokine (C-C motif) ligand 2 (CCL2) directs microglia to the site of injury or infection [7, 8]. Vascular cell adhesion molecule 1 (VCAM-1), an adhesion molecule, also plays a role in chemotaxis $[9,10]$. The activated microglia usually secrete matrix metalloproteinase-9 (MMP-9), a type of protease that degrades the extracellular matrix and membrane proteins, resulting in the recruitment and activation of immune cells. In addition, MMP-9 also plays a role in the breakdown of physiologic barriers [11, 12]. MMP9 is regulated by tissue inhibitor of metalloproteinases 1 (TIMP-1) [7, 13].

Curcumin, the active ingredient in the traditional herbal remedy and dietary spice turmeric, has anti-oxidant [14-19], anti-apoptosis [20-23], anti-fibrosis [24], and antitumorigenesis effects [25]. It was also shown to have neuroprotective effects in P23H rats, an animal model of autosomal dominant RP (AdRP) that harbors a mutation in the $\mathrm{P} 23 \mathrm{H}$ gene, partially through dissolving accumulated protein [26], reducing oxidative stress in the endoplasm reticulum, and increasing rhodopsin expression in the photoreceptors [27]. These effects of curcumin were also confirmed in P23H swine [28]. Different from $P 23 \mathrm{H}$ mutation rats, retinal degeneration $1(\mathrm{rd} 1)$ mice harbor a mutation that affects the expression of phosphodiesterase 6 beta subunit (PDE6 $\beta$ ), resulting in the accumulation of cyclic guanosine monophosphate (cGMP), and ultimately, a reduction in the number of rod cells. Activation of microglia in the retina of $\mathrm{rd} 1$ mice plays an important role in the apoptosis of photoreceptors, which eventually affects the visual function of the retina $[29,30]$. It remains unclear if curcumin delays the rapid degeneration of photoreceptors in rd1 mice or inhibits the activation of microglia and regulates the secretion of inflammatory cytokines.

In the present study, we used immunohistochemistry, electroretinogram (ERG) recordings, and real-time quantitative polymerase chain reaction (qPCR) to analyze the relationship between the apoptosis of photoreceptors and the activation and migration of microglia in the retina of rd1 mice at postnatal day 14 (P14). Then the immunomodulatory effects of curcumin were determined and the expression levels of CCL2, VCAM-1, endothelin-1 (ET-1), and TIMP-1 in the retina were examined to determine the underlying mechanism. In addition, using BV2 murine microglial cells and $661 \mathrm{~W}$ photoreceptor-derived cells, we designed a transwell co-culture system to study the effects of microglia on the apoptosis of photoreceptors as further confirmation of our results.

\section{Materials and Methods}

Mice and ethical approval

C57BL/6 J (C57) and B6.C3-Pde6 $\mathrm{b}^{\text {rd1 }} \mathrm{Hps}^{\text {le }}$ (rd1) mice were obtained from the animal facility of Third Military Medical University (TMMU, Chongqing, China) and raised in the animal facility of Southwest Hospital (the first affiliated hospital of TMMU). The mice were kept in a standard 12/12 hour light-dark cycle. All experiments and related procedures were conducted according to the guidelines for laboratory animal care and use of TMMU, the Guidelines on Care and Use of Laboratory Animals issued by the Chinese Council on Animal Research, the requirements of Laboratory Animal Welfare and Ethics Committee of TMMU, and the Guidelines from the Association for Research in Vision and Ophthalmology. 


\section{Cellular Physiology Cell Physiol Biochem 2017;44:479-493 \\ \begin{tabular}{ll|l} 
and BiOChemistry & $\begin{array}{l}\text { DOI: 10.1159/000485085 } \\
\text { Published online: November 17, } 2017\end{array}$ & $\begin{array}{l}\text { (c) } 2017 \text { The Author(s). Published by S. Karger AG, Basel } \\
\text { www.karger.com/cpb }\end{array}$ \\
\hline
\end{tabular}}

Wang et al.: Curcumin Delays Retinal Degeneration

\section{Intravitreal injections}

In rd1 mice, intravitreal injection of curcumin (Sigma Aldrich, St. Louis, MO, USA) was performed in one eye, while the contralateral eye was injected with DMSO (Sigma Aldrich, St. Louis, MO, USA) to serve as control. Using the same procedure, dimethyl sulphoxide (DMSO) was intravitreally injected as a control. C57 mice were used as controls and treated in the same way. Mice at P7 were anesthetized by intraperitoneal injection of $1 \%$ pelltobarbitalum natricum $(10 \mu \mathrm{L})$. After a drop of topical anesthetic agent (oxybuprocaine) was administered, DMSO or curcumin $(10 \mu \mathrm{M} / \mathrm{L}$ dissolved in DMSO) [31] was injected into the vitreous humor with a syringe (33G; Hamilton, Bonaduz, Switzerland). Unless otherwise indicated, intravitreal injections were performed in a final volume of $1 \mu \mathrm{L}[30,32]$.

Immunofluorescence staining and terminal deoxynucleotidyl transferase UTP nick end labelling assay

Immunofluorescence staining and terminal deoxynucleotidyl transferase UTP nick end labelling (TUNEL) assay of frozen tissue sections and cell slides were performed as previously described [33, 34]. Briefly, for frozen tissue sections, the eyeballs of the mice were enucleated and fixed in $4 \%$ paraformaldehyde at room temperature (RT) for $2 \mathrm{~h}$. Meanwhile, the anterior segments were removed under a microscope (Olympus, Tokyo, Japan). Then the eyeballs were infiltrated with $30 \%$ sucrose overnight at $4^{\circ} \mathrm{C}$. Before cutting into a $10 \mu \mathrm{m}$ thick sagittal slice by a freezing microtome (Thermo Fisher, Waltham, MA, USA), the retinas were embedded in optimal cutting temperature solution (Sakura Finetek, Torrance, CA, USA) for long-term storage at $-80^{\circ} \mathrm{C}$. For slides, the cells were fixed in $4 \%$ paraformaldehyde at RT for $30 \mathrm{~min}$. Then, both the cells and the sections were incubated in $0.3 \%$ Triton X-100 for 10 min and 5\% goat serum for 30 min at RT. For immunofluorescence staining, the sections were incubated with anti-ionized calcium binding adaptor molecule 1 (iba1) (1:750; Wako, Tokyo, Japan) and the cells were incubated with anti-ki67 antibody (1:500; Abcam, Cambridge, UK) or anti-caspase-3 antibody (1:400; Cell Signaling Technology, Danvers, MA, USA) at $4^{\circ} \mathrm{C}$ overnight, followed by incubation with Alexa Fluor488 (Molecular Probes, Life technologies, Eugene, OR, USA) for $2 \mathrm{~h}$ at $37^{\circ} \mathrm{C}$. For the TUNEL assay, the sections were incubated with buffers 1 and 2 (In Situ Cell Death Detection Kit, Roche, Basel, Switzerland), mixed at a $1: 9$ ratio, for $2 \mathrm{~h}$ at $37^{\circ} \mathrm{C}$ according to the manufacturer's instructions. The cell nuclei were counterstained with 40, 6-diamidino-2-phenylindole (DAPI; Sigma Aldrich, St. Louis, MO, USA) after washing with phosphate-buffered saline. All staining was visualized and quantified using a ZEISS LSM800 confocal microscope (ZEN Microsystems; ZEISS, Germany).

\section{$E R G$}

The ERG procedures were performed as previously described [35]. In brief, mice at P18 ( $\mathrm{n}=5$ for each time point) were adapted to darkness for at least $8 \mathrm{~h}$, and each recording procedure was done under dim red light. After anesthesia with $1 \%$ pelltobarbitalum natricum $(0.06 \mathrm{~mL})$, mice were kept warm on a heating pad and maintained at $37^{\circ}$ C. Pupils were dilated with tropicamide eye drops (Santen Pharmaceutical, Osaka, Japan). Recording electrodes were placed at the cornea, reference electrodes were inserted under the skin of the angulus oculi, and grounding electrodes were inserted in the tail. Single flash recordings were gained at a $0.5 \log _{10}\left(\mathrm{~cd} \mathrm{~s} / \mathrm{m}^{2}\right)$ light and acquired with a retinal scan system (Roland Consult, Havel, Germany).

\section{Light/dark transition test}

The light/dark transition test was performed as previously described [36]. The light/dark box (240 $\mathrm{mm} \times 130 \mathrm{~mm} \times 130 \mathrm{~mm})$ consisted of a light chamber $(160 \mathrm{~mm} \times 130 \mathrm{~mm} \times 130 \mathrm{~mm})$ and a dark chamber $(80 \mathrm{~mm} \times 80 \mathrm{~mm} \times 80 \mathrm{~mm})$ connected with a $30 \mathrm{~mm} \times 25 \mathrm{~mm}$ door in the middle (Fig. 3A) [37, 38]. The mice were dark-adapted for at least $8 \mathrm{~h}$ and stayed in a cage alone for $2 \mathrm{~min}$ before the test without any light stimulus. After the habituation period, the mice were allowed to explore both chambers for $5 \mathrm{~min}$. The test field was lit at 300 lux by a tungsten filament bulb positioned over the center of the light chamber. All mice were tested alone (only one test per mouse). After each test, the box was cleaned with alcohol.

\section{qPCR}

qPCR was carried out as previously described [39]. In brief, total RNA of each retina was extracted with $1 \mathrm{~mL}$ TRIzol Reagent (Sigma), $200 \mu \mathrm{L}$ chloroform, $500 \mu \mathrm{L}$ isopropanol, and $1 \mathrm{~mL}$ 75\% ethyl alcohol. Then the purity and concentration of the RNA were measured with a spectrophotometric instrument (Thermo Fisher). According to the manufacturer's instructions, the PrimeScript RT Reagent Kit (Takara, Tokyo, Japan) was used to carry out reverse transcription, and a SYBR Green qPCR Mix (Dongsheng Biotech, Guangzhou, 


\section{Cellular Physiology Cell Physiol Biochem 2017;44:479-493 \begin{tabular}{l|l|l} 
and BOI: 10.1159/000485085 & $\begin{array}{l}\text { C } 2017 \text { The Author(s). Published by S. Karger AG, Basel } \\
\text { www.karger.com/cpb }\end{array}$
\end{tabular} \\ Wang et al.: Curcumin Delays Retinal Degeneration}

Table 1. The primers used in RT-qPCR

\begin{tabular}{lcc}
\hline & Forward primer & Reverse primer \\
\hline Cyclophilin-A & CGAGCTCTGAGCACTGGAGA & TGGCGTGTAAAGTCACCACC \\
Chemokine (C-C motif) ligand 2 (CCL2) & CCCAATGAGTAGGCTGGAGAG & CCCATTCCTTCTTGGGGTCAG \\
Endothelin 1(ET-1) & TGTGTCTACTTCTGCCACCTG & TTTCAAGGAACGCTTGGACCT \\
Tissue inhibitor of metalloproteinase & CCCCAGAAATCAACGAGACCA & ACTCTTCACTGCGGTTCTGG \\
1(TIMP-1) & GGTCCAAGTCCGTTCTGACC & CAAACACTTGACCGTGACCG \\
Vascular cell adhesion molecule 1(VCAM-1)
\end{tabular}

Guangdong, China) was used to perform qPCR with a CFX96 Real-Time PCR System (Bio-Rad, Hercules, CA, USA). The primers were provided by Sangon Biotech (Shanghai, China) and the sequences are shown in Table 1. The PCR conditions were as follows: $30 \mathrm{~s}$ at $95^{\circ} \mathrm{C}, 41$ cycles of $5 \mathrm{~s}$ at $95^{\circ} \mathrm{C}, 30 \mathrm{~s}$ at $60^{\circ} \mathrm{C}$ followed by plate reading and then $10 \mathrm{~s}$ at $95^{\circ} \mathrm{C}$ followed by melting curve analysis $\left(65-95^{\circ} \mathrm{C}\right.$, increments of $0.5^{\circ} \mathrm{C}$ per $\left.5 \mathrm{~s}\right)$.

\section{Co-culture and treatment of BV2 and $661 W$ cells}

The 661W cells were kindly gifted by Dr. Luo of State Key Laboratory of Ophthalmology, Zhongshan Ophthalmic Center, Sun Yat-Sen University, Guangzhou, Guangdong, China [40], and the BV2 cells were provided by Dr. Guo of the Neurological Surgery Department of Southwest Hospital [30]. Cell culture was performed as previously described [16,30]. Both cell types were cultured on $60 \mathrm{~mm}$ dishes at $37^{\circ} \mathrm{C}$ in a humidified atmosphere containing $5 \% \mathrm{CO}_{2}$ with Dulbecco's Modified Eagle's Medium (DMEM; Hyclone, GE Healthcare Life Sciences, Pittsburgh, PA, USA) containing 10\% fetal bovine serum (FBS, PAN Biotech, Aidenbach, Germany) and 1\% penicillin-streptomycin (Thermo Fisher). In the following assays, the BV2 cells were seeded into 6-well plates at a concentration of $5 \times 10^{4}$ cells per well. After $17 \mathrm{~h}$, the cells were

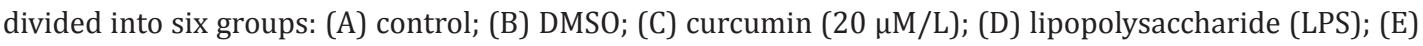
LPS+curcumin $(10 \mu \mathrm{M} / \mathrm{L})$; and (F) LPS+curcumin $(20 \mu \mathrm{M} / \mathrm{L})$. Here, LPS was used as a stimulator, as it can cause an increase in the proliferation of BV2 cells $[41,42]$. Different concentrations of curcumin were added to groups C, E, and F, and after $3 \mathrm{~h}$, the media was refreshed and LPS $(1 \mu \mathrm{g} / \mathrm{mL})$ was added to groups $\mathrm{D}, \mathrm{E}$, and F. Then, after $4 \mathrm{~h}$, the media was refreshed in each group and the cells were cultured for another $24 \mathrm{~h}$, after which the cells were collected for subsequent experiments.

\section{Transwell assay with hydrogen peroxide and curcumin}

The transwell co-culture system was designed as shown in Fig. 7A and 7B. The 661W cells were seeded into 24-well plates at a concentration of $1 \times 10^{4}$ cells per well, and the BV2 cells were seeded on the transwell (Merck Millipore, Germany) at a concentration of $2 \times 10^{3}$ cells per well, and separately cultured. After $21 \mathrm{~h}$, the cells were divided into three groups: control; hydrogen peroxide $\left(\mathrm{H}_{2} \mathrm{O}_{2}\right)$, which was used to stimulate apoptosis [16]; and $\mathrm{H}_{2} \mathrm{O}_{2}+$ curcumin. Then, $20 \mu \mathrm{M} / \mathrm{L}$ curcumin was added to BV2 cells of the $\mathrm{H}_{2} \mathrm{O}_{2}+$ curcumin group. After $2.5 \mathrm{~h}, 1 \mathrm{mM} / \mathrm{L} \mathrm{H}_{2} \mathrm{O}_{2}$ was added to the $661 \mathrm{~W}$ cells in the $\mathrm{H}_{2} \mathrm{O}_{2}$ and $\mathrm{H}_{2} \mathrm{O}_{2}+$ curcumin groups [40]. The media was refreshed after $30 \mathrm{~min}$, added to the transwells, followed by an additional $24 \mathrm{~h}$ incubation. The cells were collected for subsequent experiments.

\section{Transwell assay with LPS and curcumin}

The transwell co-culture system with LPS and curcumin was designed as shown in Fig. 8A and 8B. Briefly, the BV2 cells were seeded into 24 -well plates at a concentration of $1 \times 10^{4}$ cells per well, and the $661 \mathrm{~W}$ cells were cultured into transwells at a concentration of $2 \times 10^{3}$ cells per well; the cells were separately cultured. After $17 \mathrm{~h}$, the cells were divided into three groups: control, LPS-treated, and LPS + curcumin. Then, $20 \mu \mathrm{M} / \mathrm{L}$ curcumin was added to the BV2 cells of the LPS + curcumin group. The media was refreshed in each group after $3 \mathrm{~h}$, and LPS $(1 \mu \mathrm{g} / \mathrm{mL})$ was added to the BV2 cells of the LPS and LPS + curcumin groups. The media was refreshed again after $4 \mathrm{~h}$, followed by an additional incubation for $24 \mathrm{~h}$, and subsequent collection of the cells for subsequent experiments.

\section{Data processing and statistical analysis}

Analysis of outer nuclear layer thickness. Data from three locations ranging from the posterior pole to the retinal margin (one close to the posterior pole, one submarginal, and another at the midpoint) in three retinal sections across the optic nerve from five rd1 mice and five C57 mice $(n=5)$ were used for analysis with the Image J software (NIH, Bethesda, MD, USA). Each operation was performed in triplicate [43]. 


\section{Cellular Physiology Cell Physiol Biochem 2017;44:479-493 \begin{tabular}{l|l|l} 
and Biochemistry 10.1159/000485085 & $\begin{array}{l}\text { (C) 2017 The Author(s). Published by S. Karger AG, Basel } \\
\text { www.karger.com/cpb }\end{array}$
\end{tabular} \\ Wang et al.: Curcumin Delays Retinal Degeneration}

Cell counts. At least three frozen tissue sections from each mice and cell slides from each group $(n=5)$ were used to perform the cell count. Apoptotic cells in the outer nuclear layer (ONL) on the cell slides, microglia in the retina sections, and proliferative cells in the cell slides were counted with the Image J software (NIH). To make the results more convincing, sections crossing the optic nerve were selected. All positive cells from the TUNEL assay and iba1 staining in the whole sections were counted rather than selected locations in sections. Positive cells in each cell slide were counted in at least three different locations [33].

Quantitative assessment of ERG recordings. The graphs were processed by IGOR Pro 6.0.3.1 (WaveMetrics, Portland, OR, USA). The a-wave and b-wave amplitudes were analyzed by comparing the treated eyes with the contralateral eyes.

Calculation of time spent in light.The length of the time spent in the lit area was video-recorded and calculated using the following formula: $(\mathrm{x} / 300) \times 100 \%$, where $\mathrm{x}=$ the time $(\mathrm{s})$ in light. Four paws crossing the connecting door was defined as entering a chamber.

RNA expression analyses

RNA expression levels were analyzed using the $2^{(-\Delta \Delta \mathrm{Cq})}$ method with cyclophilin A as the control.

\section{Statistical analysis}

Data are presented as the mean \pm standard deviation. Multiple comparisons were carried out by paired-samples $t$-test and independent sample $t$-test using SPSS 20.0 software (Chicago, IL, USA). P values less than 0.05 were considered statistically significant.

\section{Results}

Curcumin inhibited apoptosis of photoreceptors in the rd1 mice

Before studying the effects of curcumin on apoptosis in rd1 mice, we first analyzed the apoptotic status in C57 mice. There were few apoptotic cells in the retinas of C57 mice at P14 (Fig. 1A, B, A1, B1), and curcumin treatment did not influence this number $(\mathrm{P}>0.05$; Fig. 1E). In rd1 mice, the apoptosis of rod cells usually appears at P8 and peaks at P14[29, 30]. In this study, the number of apoptotic cells in the ONL of DMSO-treated rd1 mice at P14 significantly increased compared with age-matched C57 mice $(\mathrm{P}<0.001 ;$ Fig. 1C, C1, E). However, curcumin treatment significantly decreased this increase of apoptosis cells in the ONL ( $\mathrm{P}<0.01$; Fig. 1D, D1, E). In addition, there was no difference in ONL thickness between the C57 control mice and the curcumin-treated C57 mice (Fig. 1A, B, A1, B1, F). However, the ONL thickness in DMSO-treated rd1 mice at P14 significantly decreased compared with the age-matched C57 mice (Fig. 1C, C1). Curcumin treatment significantly prevented the reduction of ONL thickness in rd1 mice at P14 (P<0.05; Fig. 1D, D1 F).

\section{Curcumin significantly improved the visual function of rd1 mice}

In rd1 mice, the ERG response begins to reduce after eye opening, and becomes undetectable at around P21[29]. In this study, we found that at P18, the normal ERG of C57 mice could be detected (Fig. 2A, B), and curcumin treatment did not affect the a- and b-wave amplitudes (a-wave: $84.7 \pm 24.60$ and $53.1 \pm 26.56$; b-wave: $215.4 \pm 80.39$ and $153.7 \pm 40.89$; $\mathrm{P}>0.05$; Fig. 2E, F). The ERGs of rd1 mice are nearly undetectable at low light intensity [29]. We found that DMSO-treated rd1 mice at P18 showed no amplitude of a- or b- waves (Fig. 2C, E, F). However, curcumin treatment in rd1 mice recovered those waves at P18 (Fig. 2D), especially for a-wave amplitudes (a-wave: $54.7 \pm 38.57$; b-wave: $62.2 \pm 2.99 ; \mathrm{P}_{\mathrm{a}}>0.05 ; \mathrm{P}_{\mathrm{b}}<0.01$; Fig. 2E, F). To more generally assess the visual function, we conducted behavior tests in mice using the light/dark transition model. At P18, C57 mice had good light perception, and there was no difference between the DMSO-treated and curcumin-treated C57 mice $(12.8 \pm 9.30 \%$ and $11.6 \pm 7.74 \%$ in light field, respectively; P>0.05). However, DMSO-treated rd1 mice at P18 showed no light perception $(\mathrm{P}<0.01)$, but curcumin treatment recovered the light perception $(\mathrm{P}<0.01)$. The curcumin-treated mice spent $14.4 \pm 10.56 \%$, a similar time compared to $\mathrm{C} 57$ mice in the light field ( $\mathrm{P}>0.05$; Fig. $3 \mathrm{~B}$ ). The results were consistent with the ERG results. 
Fig. 1. Curcumin protected the photoreceptors by inhibiting cellular apoptosis in rd1 mice. A-D: Whole retinal montage of TUNEL staining in the following groups of mice: (A) C57 mice, DMSO, (B) $\mathrm{C} 57$ mice, curcumin, (C) rd1 mice, DMSO, and (D) rd1 mice, curcumin. A1-D1: Enlarged image of TUNEL staining from papilla nervi optici $750 \mu \mathrm{m}$. E: Comparison of the total numbers of TUNELstained cells in the whole retina. F: Comparison of ONL thickness at dif-
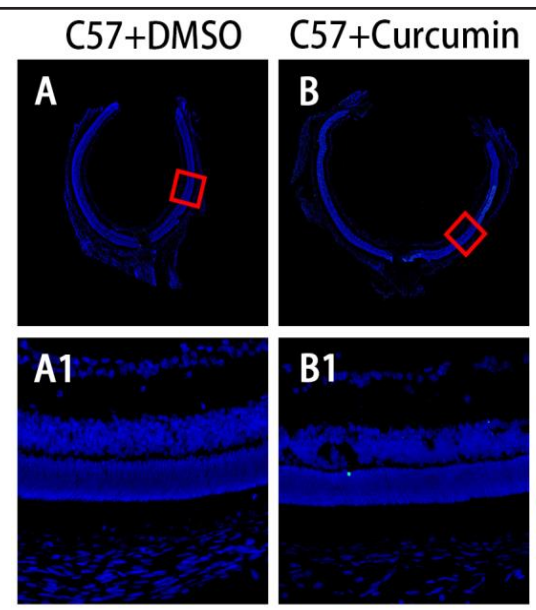

E

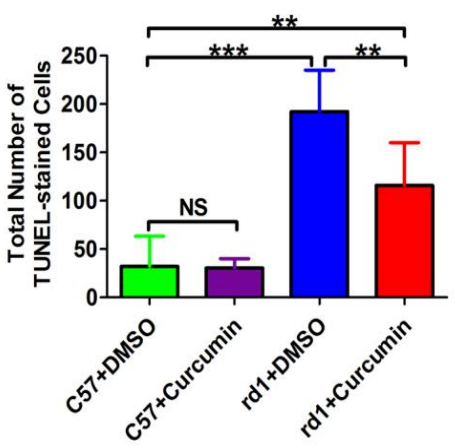

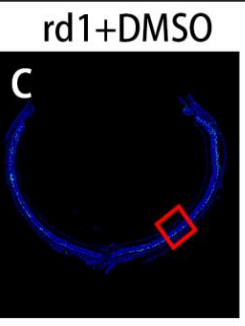
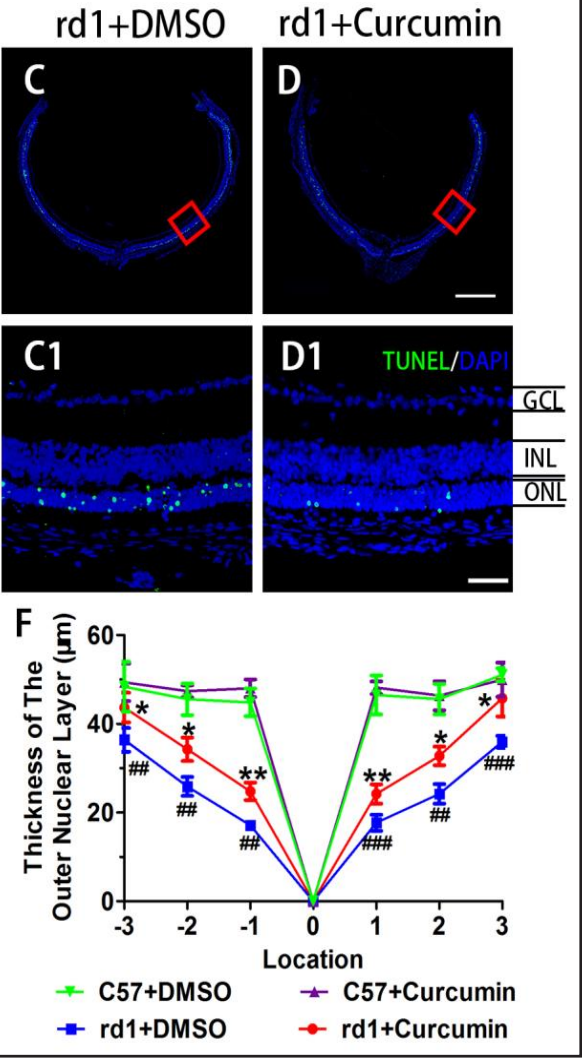
ferent locations. *: rd1+Curcumin vs rd1+DMSO; \#: rd1+DMSO vs C57+DMSO; ${ }^{*} \mathrm{P}<0.05 ;{ }^{* *} \mathrm{P}<0.01 ;{ }^{* * *} \mathrm{P}<0.001$; Scale bar: A-D $500 \mu \mathrm{m} ; \mathrm{A} 1-\mathrm{D} 150 \mu \mathrm{m}$.

Fig. 2. Curcumin partly improved visual function tested by ERG in $\mathrm{rd} 1$ mice at P18. ERG tests were performed on P18. A-D: ERG waveforms in (A) C57 mice, DMSO, (B) C57 mice, curcumin, (C) rd1 mice, DMSO, (D) rd1 mice, curcumin. E and F: Separate comparisons of the values of the (E) a-wave amplitude and (F) b-wave amplitude. ${ }^{* *} \mathrm{P}<0.01$.

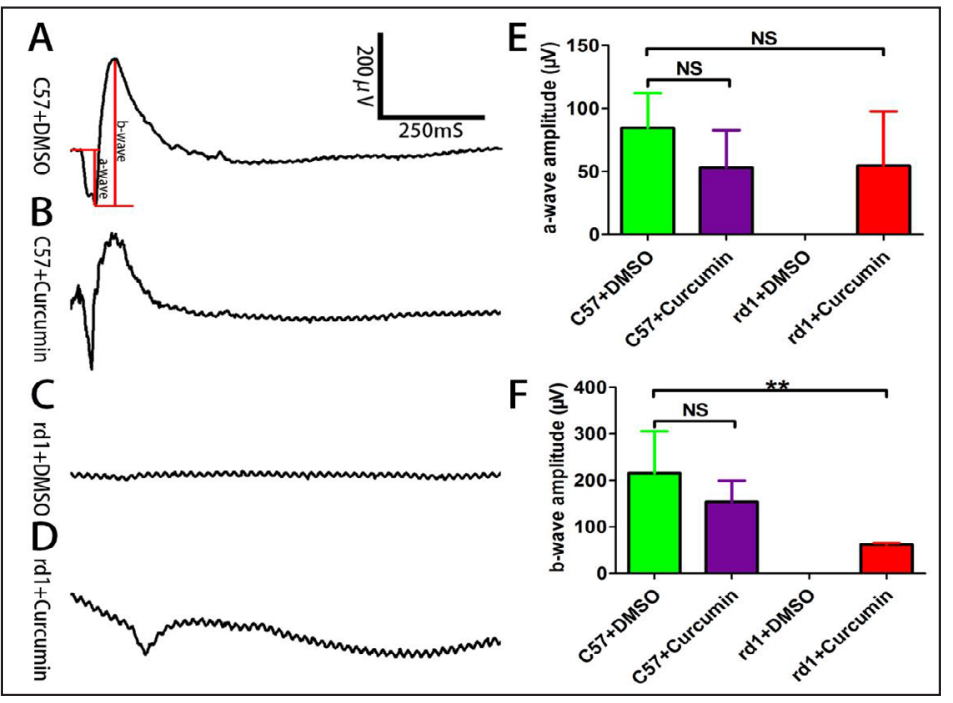

Curcumin inhibited microglia activation in the retina of $\mathrm{rd} 1$ mice

There were only a few microglia in the resting state in the outer plexiform layer of C57 mice, and curcumin treatment did not influence the number and distribution of microglia in the retina ( $>0.05$; Fig. $4 \mathrm{~A}, \mathrm{~B}, \mathrm{~A} 1, \mathrm{~B} 1, \mathrm{E})$. According to our previous results, because the apoptosis of photoreceptors occurs in the ONL of rd1 mice, there is a large number of activated microglia that migrate to the $\mathrm{ONL}$, and the number of microglia in the retina of 
Fig. 3. Curcumin partly improved visual function in light/dark transition test in rd1 mice at P18. Light/dark transition test was performed on P18. A: The light/dark transition test box consisted of an illuminated compartment (two-thirds of the floor area) and a smaller dark compartment (one-third). A small opening located at floor level in the center of the dividing wall allowed mice to freely move between the dark and light chambers. B: Comparison of time spent in the light area among four groups. ${ }^{* *} \mathrm{P}<0.01$.

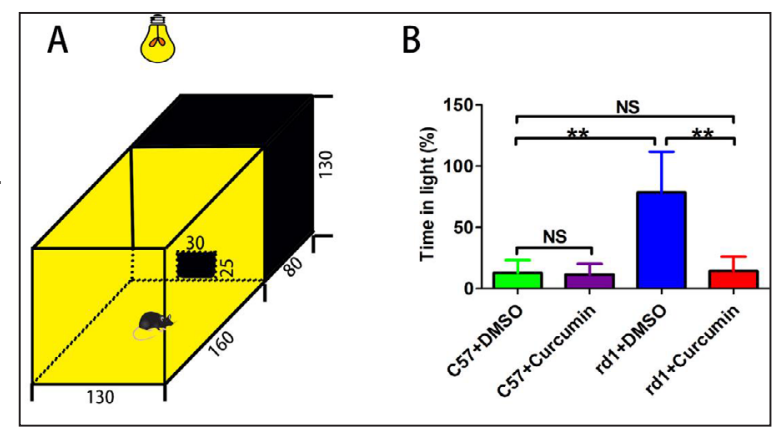

Fig. 4. Curcumin inhibited the activation of microglia in $\mathrm{rd} 1$ mice retinae. A-D: Whole retinal montage of microglia in the $(\mathrm{A})$ C57 mice, DMSO, (B) C57 mice, curcumin, (C) rd1 mice, DMSO, (D) rd1 mice, curcumin. A1-D1: Enlarged image of iba1 staining from papilla nervi optici $750 \mu \mathrm{m}$. E: Comparison of the total numbers of microglia in the whole retina. ${ }^{*} \mathrm{P}<0.05$; ${ }^{* *} \mathrm{P}<0.01$; Scale bar: A-D $500 \mu \mathrm{m}$; A1-D1 $20 \mu \mathrm{m}$.

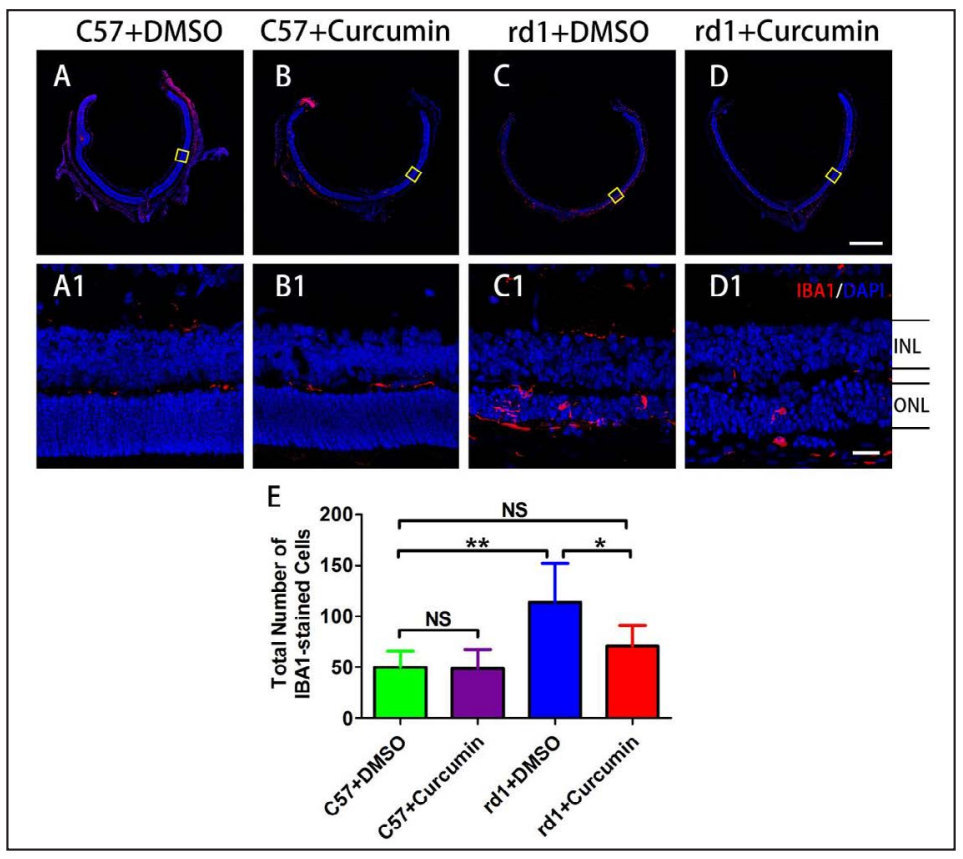

Fig. 5. Curcumin regulated the activation of microglia by promoting the secretion of CCL2, TIMP1, and VCAM1. A-D: Comparison of CCL2 (A), ET-1 (B), TIMP1 (C), and VCAM1 (D) expression levels as determined by qPCR. ${ }^{*} \mathrm{P}<0.05$; ${ }^{* *} \mathrm{P}<0.01$; ${ }^{* *} \mathrm{P}<0.001$

the rd1 mice retina peaks at P14 [30]. In the present study, the microglia in the retinas of rd1 mice at P14 was activated and had the typical round and amoeboid-like shape. The microglia migrated from the inner nuclear layer to the $\mathrm{ONL}$, where the photoreceptors degenerated and underwent apoptosis. The number of microglia in the retinas of rd1 mice at P14 treated with DMSO significantly increased compared with the age-matched untreated C57 mice $(\mathrm{P}<0.01$; Fig. 4C, C1, E), and curcumin treatment significantly reduced this number of increased microglia $(\mathrm{P}<0.05$;

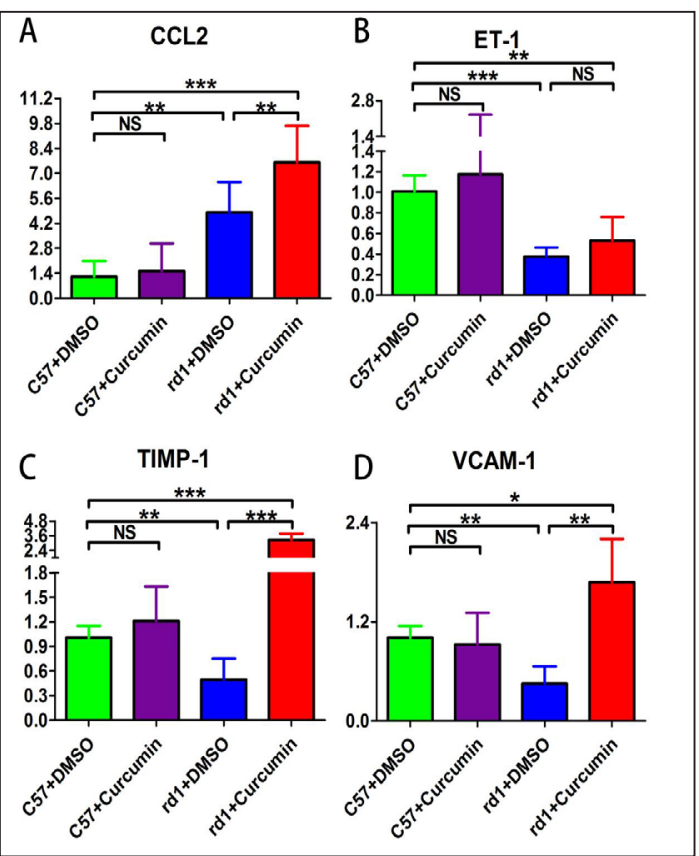
Fig. 4D, D1, E). 


\section{Cellular Physiology

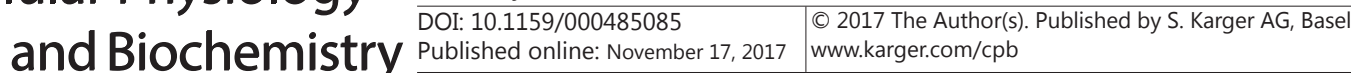

Fig. 6. Curcumin inhibited the LPS-induced proliferation of BV2 cells. A-F: Immunofluorescence staining of ki67-positive BV2 cells (green) and DAPI (blue) in the (A) control, (B) DMSO, (C) curcumin, (D) LPS, (E) LPS $+\operatorname{curcumin}(10 \mu \mathrm{M} / \mathrm{L})$, (F) LPS + curcumin (20 $\mu \mathrm{M} / \mathrm{L})$ groups. A1-F1: Enlarged image of ki67 staining. G: Comparison of the ki67-positive rate of BV2 cells. ${ }^{*} \mathrm{P}<0.05 ; \quad * * \mathrm{P}<0.01$; Scale bar: A-F $50 \mu \mathrm{m}$; A1-F1 $20 \mu \mathrm{m}$.
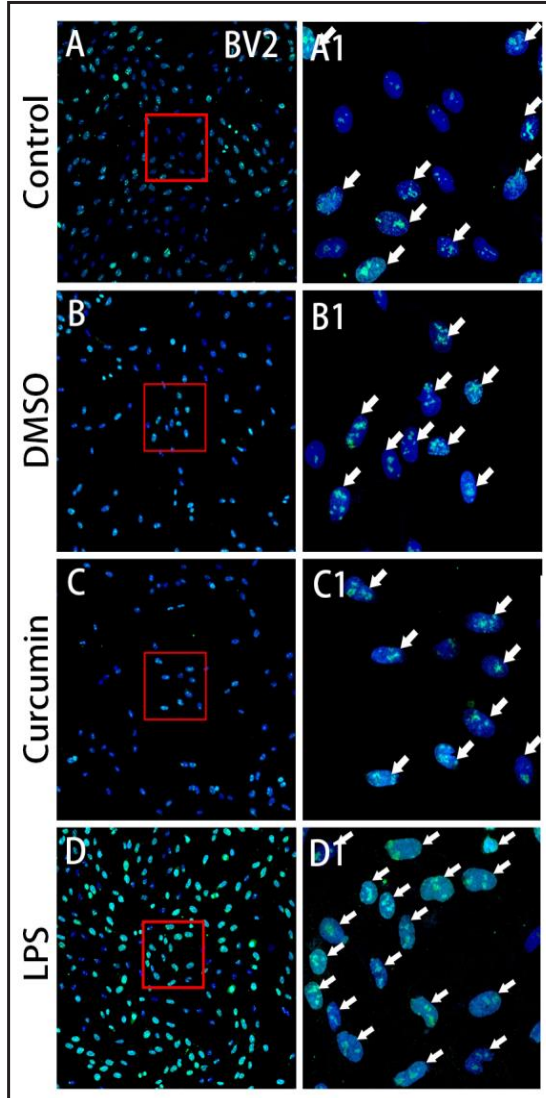
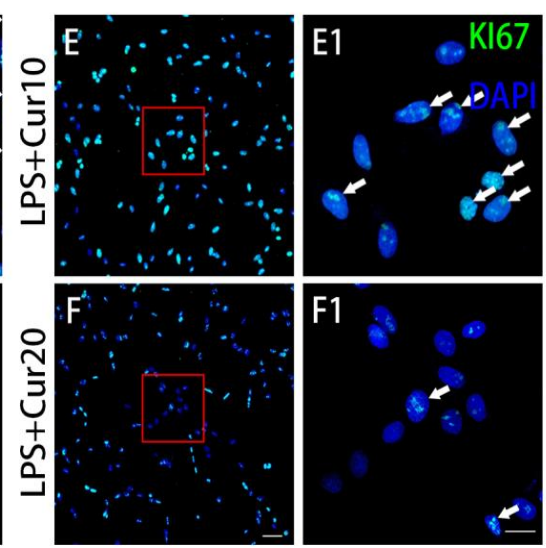

G

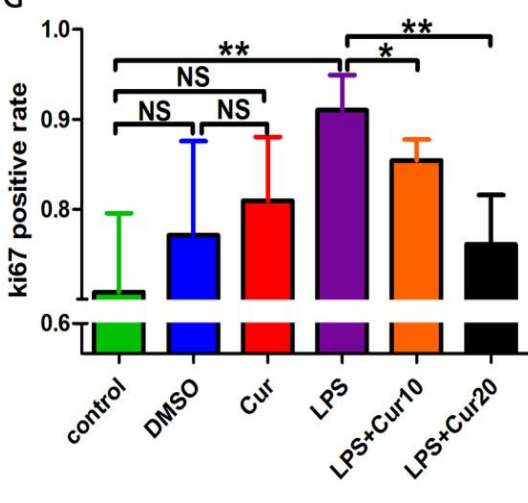

Curcumin regulated the expression levels of CCL2, TIMP-1, ET-1, and VCAM-1

After finding evidence of the immunomodulatory effects of curcumin, we were interested in determining the underlying mechanism. Thus, the expression of CCL2 in the retina was examined to study the effects of curcumin on chemokine secretion. The expression of CCL2 in the groups of C57 mice was low, and there was no significant difference between DMSOand curcumin-treated C57 mice. However, CCL2 expression significantly increased $(\mathrm{P}<0.01)$ at P14 in DMSO-treated rd1 mice compared with age-matched C57 mice. In addition, curcumin treatment significantly upregulated the expression of CCL2 even more at P14 in rd1 mice $(\mathrm{P}<0.01$; Fig. 5A). There was no significant difference in the expression level of ET-1 in the retina between DMSO- and curcumin-treated C57 or rd1 mice ( $P>0.05)$; however, its expression level was significantly decreased in the retina of rd1 mice at P14 compared with age-matched C57 mice $(\mathrm{P}<0.01$; Fig. 5B). For TIMP-1, there was no significant difference in expression level between DMSO- and curcumin-treated C57 mice ( $>0.05)$, whereas the expression level in the retina of $\mathrm{rd} 1$ mice was significantly decreased $(\mathrm{P}<0.01)$. However, curcumin treatment significantly reversed the decreased expression level of TIMP-1 $(\mathrm{P}<0.005$, Fig. 5C). There was no significant difference in VACM-1 expression in the retina of DMSO- and curcumin-treated C57 mice (P>0.05), whereas the expression in DMSOtreated $\mathrm{rd} 1$ mice was significantly downregulated $(\mathrm{P}<0.01)$. However, curcumin treatment significantly reversed this decreased expression $(\mathrm{P}<0.05$, Fig. 5D).

Curcumin decreased the apoptosis of photoreceptors by inhibiting microglia proliferation in vitro

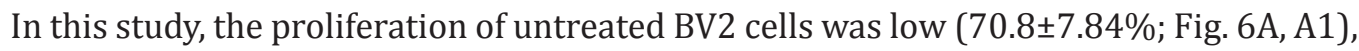
and not influenced by curcumin or its solvent, DMSO $(81.0 \pm 6.33 \%$ or $77.1 \pm 9.35 \%$; $\mathrm{P}>0.05$; Fig. 6B, C, B1, C1, G). However, LPS treatment significantly increased the proliferation of BV2 
Fig. 7. Curcumin inhibited the proliferation of BV2 cells induced by $661 \mathrm{~W}$ cells with high apoptosis rate. A: The schedule of the in vitro study design. B: The mode pattern of co-culture system showing transwell inserts in the 24-well plates. C-E: Immunofluorescence staining of ki67-positive BV2 cells (green) and DAPI (blue) in the (C) control, (D) $\mathrm{H}_{2} \mathrm{O}_{2}$, (E) $\mathrm{H}_{2} \mathrm{O}_{2}$ +curcumin. C1E1: Enlarged image of ki67 staining. F: Comparison of the ki67-positive rate of BV2 cells. ${ }^{* * *} \mathrm{P}<0.001$; Scale bar: A-F $50 \mu \mathrm{m}$; A1-F1 $20 \mu \mathrm{m}$.

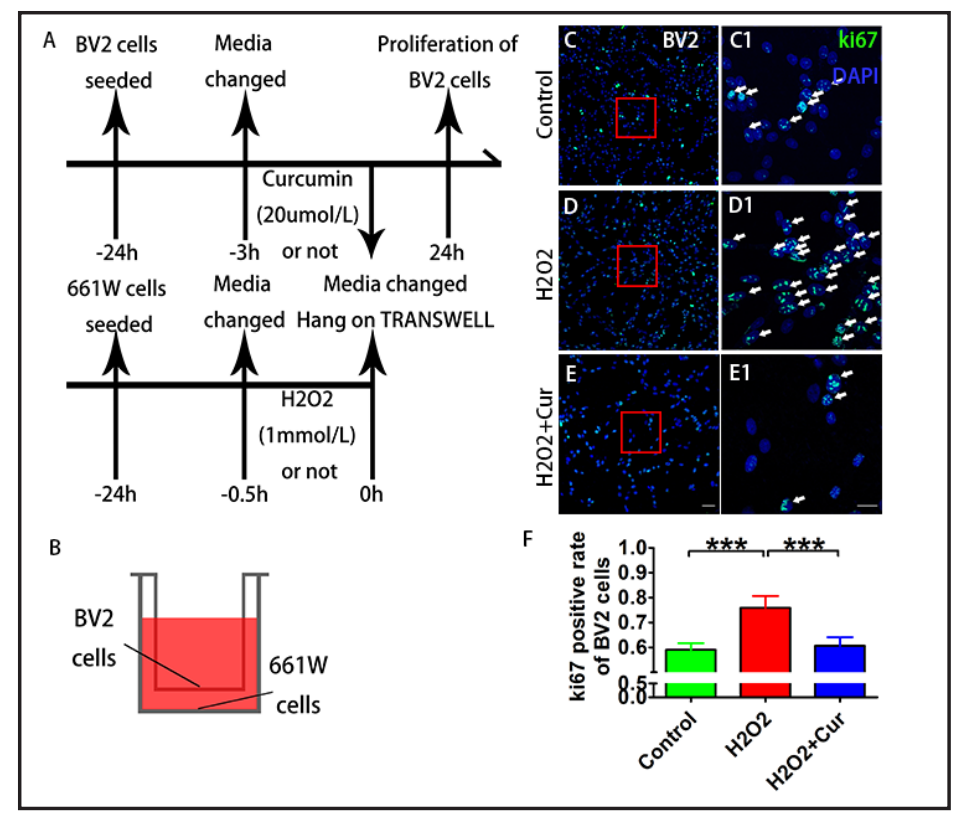

Fig. 8. Curcumin inhibited the apoptosis of $661 \mathrm{~W}$ cells induced by BV2 cells with a high proliferation rate. A: The schedule of the in vitro study design. B: The mode pattern of co-culture system showing the transwell inserts in the 24-well plates. C-E: Immunofluorescence staining of caspase-3 positive $661 \mathrm{~W}$ cells (green) and DAPI (blue) in the (C) control, (D) LPS, (E) LPS + curcumin. C1E1: Enlarged image of caspase-3 staining. F: Comparison of the caspase- 3 positive rate of $661 \mathrm{~W}$ cells. ***P $<0.001$; Scale bar: A-F $50 \mu \mathrm{m}$; A1-F1 $20 \mu \mathrm{m}$.

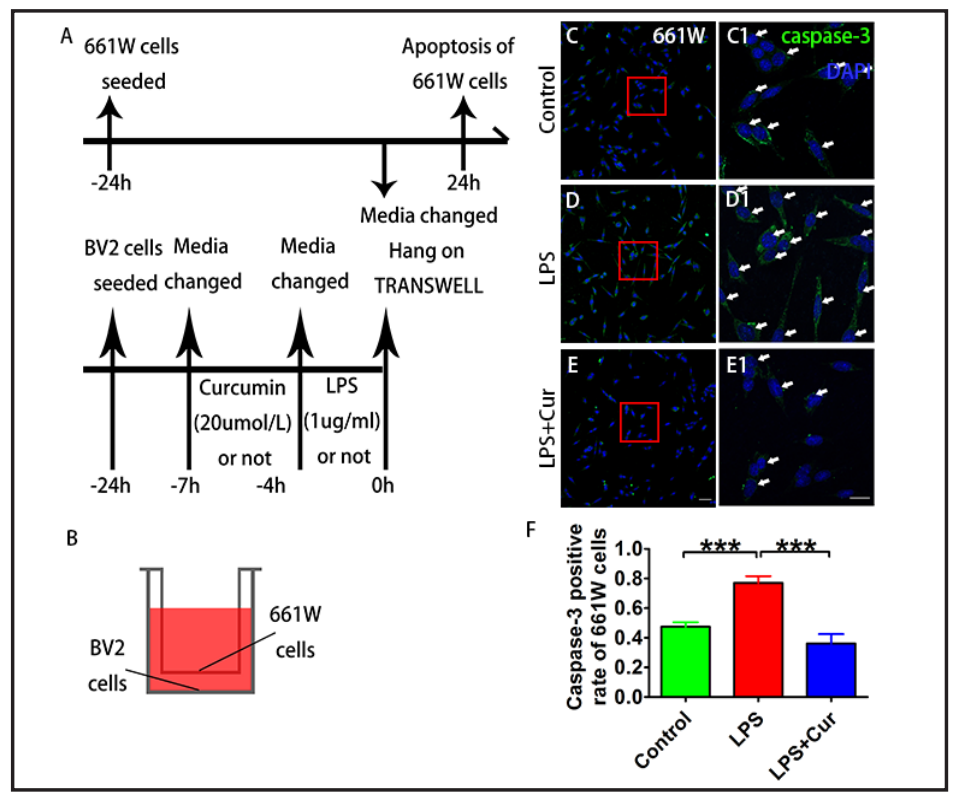

cells (91.0 $\pm 3.51 \%$; $\mathrm{P}<0.01$; Fig. 6D, D1, G), which was significantly antagonized by curcumin, especially at a concentration of $20 \mu \mathrm{M} / \mathrm{L}$ compared with $10 \mu \mathrm{M} / \mathrm{L}(76.1 \pm 4.92 \%, \mathrm{P}<0.01$ and 85.4 $\pm 2.06 \%$, P<0.05; Fig. 6E, F, E1, F1, G). Thus, $20 \mu \mathrm{M} / \mathrm{L}$ curcumin was used in subsequent experiments.

The high apoptosis rate of $661 \mathrm{~W}$ cells increased the proliferation of BV2 cells, which could be inhibited by curcumin treatment

We used a transwell co-culture system to analyze the effects of apoptosis of $661 \mathrm{~W}$ cells on the proliferation of BV2 cells and the function of curcumin (Fig. 7D, E). The proliferation

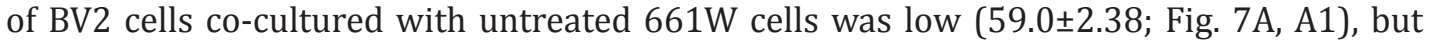
$\mathrm{H}_{2} \mathrm{O}_{2}$ treatment of $661 \mathrm{~W}$ cells significantly increased the proliferation of the co-cultured BV2 cells (75.9 \pm 4.25 ; P<0.001; Fig. 7B, B1, F). On the other hand, curcumin treatment of BV2 cells significantly antagonized the increased proliferation $(60.7 \pm 3.03 ; \mathrm{P}<0.001 ; \mathrm{Fig} .7 \mathrm{C}, \mathrm{C} 1, \mathrm{~F})$.

\section{KARGER}




\section{Cellular Physiology Cell Physiol Biochem 2017;44:479-493 \begin{tabular}{l|l|l} 
DOI: 10.1159/000485085 & $\begin{array}{l}\text { C } 2017 \text { The Author(s). Published by S. Karger AG, Basel } \\
\text { www.karger.com/cpb }\end{array}$
\end{tabular} \\ Wang et al.: Curcumin Delays Retinal Degeneration}

The high proliferation of BV2 cells increased the apoptosis of $661 \mathrm{~W}$ cells, which was inhibited by curcumin

To further show the effects of curcumin, we used the transwell co-culture system to analyze the effects of BV2 proliferation on $661 \mathrm{~W}$ cells and the function of curcumin (Fig. 8D, E). The apoptosis of $661 \mathrm{~W}$ cells co-cultured with untreated BV2 cells was low $(47.5 \pm 2.63 \%$; Fig. 8A, A1), but LPS treatment of BV2 cells significantly increased apoptosis of the cocultured $661 \mathrm{~W}$ cells $(77.0 \pm 4.12 \%$; $\mathrm{P}<0.001$; Fig. 8B, B1, F). On the other hand, curcumin treatment of BV2 cells significantly antagonized the increased apoptosis $(36.1 \pm 5.70 \%$; $\mathrm{P}<0.001$; Fig. 8C, C1, F).

\section{Discussion}

Curcumin has been well studied in neurodegenerative diseases such as Alzheimer's disease, in which it plays a role in epigenetics, modulating gene expression by changing environmental factors to cause a relative steady state. Its main effects on neurodegeneration diseases include anti-inflammation through the NF- $\kappa B$ pathway, anti-oxidant effects through the Nrf2 pathway, and disaggregation of polymers [44-47].

The present study showed that 7-day treatment of curcumin in rd1 mice significantly reduced the apoptosis of photoreceptor cells at $\mathrm{P7}$, and protected the visual function of $\mathrm{rd} 1$ mice at P18. In addition, curcumin inhibited the activation of microglia and significantly regulated the expression of CCL2, VCAM-1, TIMP-1 in the retina of rd1 mice at P14. The underlying mechanism of its action appeared to be causing a decrease in photoreceptor apoptosis by suppressing the activation of microglia in vitro.

As a neurodegenerative disease, RP induces microglia activation [48]. Microglia cells, the first responders to cell damage within the retina, are involved in injury repair and inflammatory state [49]. Typically, activated microglia have two sources from which to play their respective roles: resident microglia tend of the M1 type mainly function in proinflammation and neurotoxin, whereas infiltrated bone marrow (BM)-derived monocytes tend to be of the M2 type with the main function of neuroprotection [3]. In the pathology of $\mathrm{RP}$, the infiltration of BM-derived monocytes is restricted by the physiologic blood-retinal barrier (BRB), which causes neuroprotective function loss in the BM-derived monocytes, and may be the reason the damage in RP worsens rather than being repaired $[3,50]$. CCL2, also called monocyte chemotactic protein 1 , is usually secreted by microglia, nerve cells, and astrocytes, and bonds with the surface receptor CCR2 of inflammatory cells. The main function of CCL2 is to recruit microglia [51,52], especially BM-derived monocytes, to the site of injury through alerting the BRB[53,54]. VCAM-1, another important endothelial-related molecule in chemotaxis, plays a role in the infiltration of BM-derived monocytes $[10,55]$. TIMP-1, an inhibitor of MMPs, together with MMPs plays a role in alerting the BRB[11]. In the present study, the expression of these endothelial-related molecules significantly changed in rd1 mice, compared with age-matched C57 mice, which might have been the reason for the observed restriction of BM-derived monocyte infiltration. While, curcumin significantly changed the expression of CCL2, VCAM-1 and TIMP-1, it particularly reversed the low expression of VCAM-1 and TIMP-1. Thus, curcumin may be affective in facilitating BM-derived monocyte infiltration into the retina, thereby improving the state of the damaged retina. The in vitro results indicated that apoptosis of the photoreceptors promoted the activation of microglia, and in turn, activated microglia accelerated the apoptosis of photoreceptors. This vicious circle explains the progressive worsening of retinal injury observed in RP.

Immune cell-induced apoptosis is just one mechanism underlying apoptosis in RP; about $30 \%$ apoptosis is induced by increasing ATP levels [56]. According to our results, curcumin completely inhibited microglia activation in the retinas of $\mathrm{rd} 1$ mice, but did not inhibit the apoptosis of photoreceptors. These results suggest that there are other mechanisms that induce apoptosis, for example, an increase in ATP levels. Thus, the effects of curcumin on ATP should be addressed in further studies. 
Curcumin treatment prevented complete loss of visual function in rd1 mice. In the P23H animal models, curcumin disrupted protein aggregates and decreased expression of endoplasmic reticulum stress markers in vitro $[27,28]$. However, in rd1 mice, curcumin inhibited the activation of microglia and regulated the expression of immune-related factors in vivo. These differences reflected that the P23H mutant induced RP by abnormal protein aggregation and ER oxidant stress, but the PDE6 $\beta$ mutant induced RP by neuroinflammation. The effects of curcumin on RP were exactly the same as its main effects in neurodegenerative diseases. Thus, our results demonstrate the anti-inflammation effects of curcumin in neurodegenerative diseases.

According to our results, curcumin might only slow down the process of RP rather than reverse it, because it can inhibit the increasing number of microglia entirely, but cannot inhibit apoptosis. However, rod cells might secret some cytokines to protect cone cells [5759]. So, delaying the process of rod cell degeneration is beneficial to both rod and cone cells.

Although the drug-delivery of curcumin is mostly gavage [25], oral [60], or by intraperitoneal injection [61], and rarely by intravitreal injection [31], we chose intravitreal injection to achieve the effective local concentration rapidly. In addition, intravitreal injection can be used to distinguish between the treated and untreated eye of a mouse [6266]. Furthermore, using curcumin in utero might inhibit degeneration entirely [28], given that it might be a better way to use curcumin prenatally for those who at high risk for RP. However, for patients who already have RP, it is possible that the earlier curcumin is taken, the better the effects that will result, although the condition will not be entirely reversed. To achieve local effective concentrations as soon as possible, intravitreal injections might be the best choice. Future studies on the dosage and frequency of curcumin treatment using intravitreal injection are needed.

Although curcumin can across blood brain barrier and BRB[27], its poor solubility in water makes delivery a challenge. Maria designed a water-soluble complex of curcumin with cyclodextrins to make eyedrop delivery possible [67]. In addition, nanoparticles, which have been extensively studied in recent years, are being used as novel drug delivery systems because of their characteristics including biodegradability, non-toxicity, and hydrophilicity. In fact, Ayadi demonstrated that starch nanoparticles allowed curcumin to dissolve in water and undergo controlled release. In addition, Ayadi synthesized nanoparticles less than $10 \mathrm{~nm}$ in size to enable them to be excreted from the renal system and easily reach the necessary location [68]. Curcumin-loaded nanoparticles have already been used in several animal models of disease, especially cancer [68-74].

\section{Conclusion}

As a multifunctional drug with anti-inflammation effects, curcumin protected photoreceptor cells by regulating microglia, resulting in the improved visual function of rd1 mice. Thus, curcumin may have therapeutic benefits in patients with RP.

\section{Disclosure Statement}

The authors have no Disclosure Statement to declare.

\section{Acknowledgements}

We thank LetPub for its linguistic assistance during the preparation of this manuscript. This study was supported by the National Natural Science Foundation of China (No.31271051, 81570890) and Foundation of Southwest Hospital (No.SWH2016LHYS-03, SWH2016JG021). 


\section{Cellular Physiology Cell Physiol Biochem 2017;44:479-493 \begin{tabular}{l|l|l} 
and Biochemistry 10.1159/000485085 & $\begin{array}{l}\text { (c) } 2017 \text { The Author(s). Published by S. Karger AG, Basel } \\
\text { www.karger.com/cpb }\end{array}$
\end{tabular}}

Wang et al:: Curcumin Delays Retinal Degeneration

\section{References}

1 Kalloniatis M, Nivison-Smith L, Chua J, Acosta ML, Fletcher EL: Using the rd1 mouse to understand functional and anatomical retinal remodelling and treatment implications in retinitis pigmentosa: a review. Exp Eye Res 2016;150:106-121.

2 Hanisch UK, Kettenmann H: Microglia: active sensor and versatile effector cells in the normal and pathologic brain. Nat Neurosci 2007;10:1387-1394.

-3 Jin N, Gao L, Fan X, Xu H: Friend or foe? resident microglia vs bone marrow-derived microglia and their roles in the retinal degeneration. Mol Neurobiol 2017;54:4094-4112.

-4 Langmann T: Microglia activation in retinal degeneration. J Leukoc Biol 2007;81:1345-1351.

5 Peng B, Xiao J, Wang K, So KF, Tipoe GL, Lin B: Suppression of microglial activation is neuroprotective in a mouse model of human retinitis pigmentosa. J Neurosci 2014;34:8139-8150.

-6 Kohno H, Maeda T, Perusek L, Pearlman E, Maeda A: CCL3 production by microglial cells modulates disease severity in murine models of retinal degeneration. J Immunol 2014;192:3816-3827.

-7 Jakobsson J, Bjerke M, Sahebi S, Isgren A, Ekman CJ, Sellgren C, Olsson B, Zetterberg H, Blennow K, Palsson E, Landen M: Monocyte and microglial activation in patients with mood-stabilized bipolar disorder. J Psychiatry Neurosci 2015;40:250-258.

8 Miotla Zarebska J, Chanalaris A, Driscoll C, Burleigh A, Miller RE, Malfait AM, Stott B, Vincent TL: CCL2 and CCR2 regulate pain-related behaviour and early gene expression in post-traumatic murine osteoarthritis but contribute little to chondropathy. Osteoarthritis Cartilage 2017;25:406-412.

-9 Bhat SA, Goel R, Shukla R, Hanif K: Platelet CD40L induces activation of astrocytes and microglia in hypertension. Brain Behav Immun 2017;59:173-189.

-10 Ferretti MT, Merlini M, Spani C, Gericke C, Schweizer N, Enzmann G, Engelhardt B, Kulic L, Suter T, Nitsch RM: T-cell brain infiltration and immature antigen-presenting cells in transgenic models of Alzheimer's disease-like cerebral amyloidosis. Brain Behav Immun 2016;54:211-225.

11 Bhatt RS, Kothari ST, Gohil DJ, D’Souza M, Chowdhary AS: Novel evidence of microglial immune response in impairment of Dengue infection of CNS. Immunobiology 2015;220:1170-1176.

12 Liu H, Angert M, Nishihara T, Shubayev I, Dolkas J, Shubayev VI: Spinal glia division contributes to conditioning lesion-induced axon regeneration into the injured spinal cord: potential role of cyclic AMPinduced tissue inhibitor of metalloproteinase-1. J Neuropathol Exp Neurol 2015;74:500-511.

-13 Ahuja S, Ahuja P, Caffe AR, Ekstrom P, Abrahamson M, van Veen T: rd1 mouse retina shows imbalance in cellular distribution and levels of TIMP-1/MMP-9, TIMP-2/MMP-2 and sulfated glycosaminoglycans. Ophthalmic Res 2006;38:125-136.

14 Zheng L, Li Y, Li X, Kou J, Zhong Z, Jiang Y, Liu Z, Tian Y, Yang L: Combination of hydroxyl acetylated curcumin and ultrasound induces macrophage autophagy with anti-apoptotic and anti-lipid aggregation effects. Cell Physiol Biochem 2016;39:1746-1760.

15 Li Y, Zou X, Cao K, Xu J, Yue T, Dai F, Zhou B, Lu W, Feng Z, Liu J: Curcumin analog 1, 5-bis (2-trifluoromethylphenyl)-1, 4-pentadien-3-one exhibits enhanced ability on Nrf2 activation and protection against acrolein-induced ARPE-19 cell toxicity. Toxicol Appl Pharmacol 2013;272:726-735.

-16 Mandal MN, Patlolla JM, Zheng L, Agbaga MP, Tran JT, Wicker L, Kasus-Jacobi A, Elliott MH, Rao CV, Anderson RE: Curcumin protects retinal cells from light-and oxidant stress-induced cell death. Free Radic Biol Med 2009;46:672-679.

17 Morabito R, Falliti G, Geraci A, Spada GL, Marino A: Curcumin protects -SH groups and sulphate transport after oxidative damage in human erythrocytes. Cell Physiol Biochem 2015;36:345-357.

18 Zhu W, Wu Y, Meng YF, Wang JY, Xu M, Tao JJ, Lu J: Effect of curcumin on aging retinal pigment epithelial cells. Drug Des Devel Ther 2015;9:5337-5344.

19 Yang W, Fu J, Yu M, Wang D, Rong Y, Yao P, Nussler AK, Yan H, Liu L: Effects of three kinds of curcuminoids on anti-oxidative system and membrane deformation of human peripheral blood erythrocytes in high glucose levels. Cell Physiol Biochem 2015;35:789-802.

20 Park SI, Lee EH, Kim SR, Jang YP: Anti-apoptotic effects of Curcuma longa L. extract and its curcuminoids against blue light-induced cytotoxicity in A2E-laden human retinal pigment epithelial cells. J Pharm Pharmacol 2017;69:334-340. 


\section{Cellular Physiology Cell Physiol Biochem 2017;44:479-493 \begin{tabular}{l|l|l} 
and Biochemistry & DOI: 10.1159/000485085 & (c) 2017 The Author(s). Published by S. Karger AG, Basel \\
www.karger.com/cpb
\end{tabular} \\ Wang et al.: Curcumin Delays Retinal Degeneration}

21 Li J, Wang P, Ying J, Chen Z, Yu S: Curcumin attenuates retinal vascular leakage by inhibiting calcium/calmodulindependent protein kinase ii activity in streptozotocin-induced diabetes. Cell Physiol Biochem 2016;39:11961208.

-22 Zhou Y, Zhang T, Wang X, Wei X, Chen Y, Guo L, Zhang J, Wang C: Curcumin modulates macrophage polarization through the inhibition of the toll-like receptor 4 expression and its signaling pathways. Cell Physiol Biochem 2015;36:631-641.

23 Emoto Y, Yoshizawa K, Uehara N, Kinoshita Y, Yuri T, Shikata N, Tsubura A: Curcumin suppresses N-methyl$\mathrm{N}$-nitrosourea-induced photoreceptor apoptosis in Sprague-Dawley rats. In vivo 2013;27:583-590.

-24 Fu XY, Zhang DW, Li YD, Zhao PW, Tang YQ Niu JZ, Li Y: Curcumin treatment suppresses CCR7 expression and the differentiation and migration of human circulating fibrocytes. Cell Physiol Biochem 2015;35:489498.

25 Wang LL, Sun Y, Huang K, Zheng L: Curcumin, a potential therapeutic candidate for retinal diseases. Mol Nutr Food Res 2013;57:1557-1568.

26 Khajavi M, Inoue K, Wiszniewski W, Ohyama T, Snipes GJ, Lupski JR: Curcumin treatment abrogates endoplasmic reticulum retention and aggregation-induced apoptosis associated with neuropathy-causing myelin protein zero-truncating mutants. Am J Hum Genet 2005;77:841-850.

27 Vasireddy V, Chavali VR, Joseph VT, Kadam R, Lin JH, Jamison JA, Kompella UB, Reddy GB, Ayyagari R: Rescue of photoreceptor degeneration by curcumin in transgenic rats with P23H rhodopsin mutation. PLoS One 2011;6:e21193.

28 Scott PA, Kaplan HJ, McCall MA: Prenatal exposure to curcumin protects rod photoreceptors in a transgenic pro23his swine model of retinitis pigmentosa. Transl Vis Sci Technol 2015;4:5.

29 Gibson R, Fletcher EL, Vingrys AJ, Zhu Y, Vessey KA, Kalloniatis M: Functional and neurochemical development in the normal and degenerating mouse retina. J Comp Neurol 2013;521:1251-1267.

-30 Li Z, Zeng Y, Chen X, Li Q Wu W, Xue L, Xu H, Yin ZQ: Neural stem cells transplanted to the subretinal space of rd1 mice delay retinal degeneration by suppressing microglia activation. Cytotherapy 2016;18:771-784.

-31 Burugula B, Ganesh BS, Chintala SK: Curcumin attenuates staurosporine-mediated death of retinal ganglion cells. Invest Ophthalmol Vis Sci 2011;52:4263-4273.

-32 Jung G, Sun J, Petrowitz B, Riecken K, Kruszewski K, Jankowiak W, Kunst F, Skevas C, Richard G, Fehse B, Bartsch U: Genetically modified neural stem cells for a local and sustained delivery of neuroprotective factors to the dystrophic mouse retina. Stem Cells Transl Med 2013;2:1001-1010.

33 Gao L, Chen X, Tang Y, Zhao J, Li Q, Fan X, Xu H, Yin ZQ: Neuroprotective effect of memantine on the retinal ganglion cells of APPswe/PS1DeltaE9 mice and its immunomodulatory mechanisms. Exp Eye Res 2015;135:47-58.

-34 Jian Q Tao Z, Li Y, Yin ZQ: Acute retinal injury and the relationship between nerve growth factor, Notch1 transcription and short-lived dedifferentiation transient changes of mammalian Muller cells. Vision Res 2015;110:107-117.

-35 van Wyk M, Schneider S, Kleinlogel S: Variable phenotypic expressivity in inbred retinal degeneration mouse lines: a comparative study of $\mathrm{C} 3 \mathrm{H} / \mathrm{HeOu}$ and FVB/N rd1 mice. Mol Vis 2015;21:811-827.

-36 Chen X, Chen Z, Li Z, Zhao C, Zeng Y, Zou T, Fu C, Liu X, Xu H, Yin ZQ: Grafted c-kit+/SSEA1- eye-wall progenitor cells delay retinal degeneration in mice by regulating neural plasticity and forming new graftto-host synapses. Stem Cell Res Ther 2016;7:191.

37 Errijgers V, Van Dam D, Gantois I, Van Ginneken CJ, Grossman AW, D’Hooge R, De Deyn PP, Kooy RF: FVB.129P2-Pde6b(+) Tyr(c-ch)/Ant, a sighted variant of the FVB/N mouse strain suitable for behavioral analysis. Genes Brain Behav 2007;6:552-557.

38 Lin B, Koizumi A, Tanaka N, Panda S, Masland RH: Restoration of visual function in retinal degeneration mice by ectopic expression of melanopsin. Proc Natl Acad Sci U S A 2008;105:16009-16014.

39 Wu W, Qu Y, Hu N, Zeng Y, Yang J, Xu H, Yin ZQ: A cell electrofusion chip for somatic cells reprogramming. PLoS One 2015;10:e0131966.

40 Ma W, Zhu X, Ding X, Li T, Hu Y, Hu X, Yuan L, Lei L, Hu A, Luo Y, Tang S: Protective effects of SS31 on tBHP induced oxidative damage in 661W cells. Mol Med Rep 2015;12:5026-5034.

41 Jin CY, Lee JD, Park C, Choi YH, Kim GY: Curcumin attenuates the release of pro-inflammatory cytokines in lipopolysaccharide-stimulated BV2 microglia. Acta Pharmacol Sin 2007;28:1645-1651. 


\section{Cellular Physiology Cell Physiol Biochem 2017;44:479-493 \begin{tabular}{l|l|l} 
DOI: 101159/000485085 & 2017 The Author(s). Published by S. Karger AG, Basel \\
\hline
\end{tabular} and BiOChemistry Published online: November 17, 2017 www.karger.com/cpb}

Wang et al.: Curcumin Delays Retinal Degeneration

-42 Kang G, Kong PJ, Yuh YJ, Lim SY, Yim SV, Chun W, Kim SS: Curcumin suppresses lipopolysaccharide-induced cyclooxygenase-2 expression by inhibiting activator protein 1 and nuclear factor kappab bindings in BV2 microglial cells. J Pharmacol Sci 2004;94:325-328.

43 He X, Sun D, Chen S, Xu H: Activation of liver X receptor delayed the retinal degeneration of rd1 mice through modulation of the immunological function of glia. Oncotarget 2017;8:32068-32082.

44 Bigford GE, Del Rossi G: Supplemental substances derived from foods as adjunctive therapeutic agents for treatment of neurodegenerative diseases and disorders. Adv Nutr 2014;5:394-403.

-45 Borre YE, Panagaki T, Koelink PJ, Morgan ME, Hendriksen H, Garssen J, Kraneveld AD, Olivier B, Oosting RS: Neuroprotective and cognitive enhancing effects of a multi-targeted food intervention in an animal model of neurodegeneration and depression. Neuropharmacology 2014;79:738-749.

46 Corbi G, Conti V, Davinelli S, Scapagnini G, Filippelli A, Ferrara N: Dietary phytochemicals in neuroimmunoaging: a new therapeutic possibility for humans? Front Pharmacol 2016;7:364.

47 Rahimifard M, Maqbool F, Moeini-Nodeh S, Niaz K, Abdollahi M, Braidy N, Nabavi SM, Nabavi SF: Targeting the TLR4 signaling pathway by polyphenols: a novel therapeutic strategy for neuroinflammation. Ageing Res Rev 2017;36:11-19.

48 Koso H, Tsuhako A, Lai CY, Baba Y, Otsu M, Ueno K, Nagasaki M, Suzuki Y, Watanabe S: Conditional rod photoreceptor ablation reveals Sall1 as a microglial marker and regulator of microglial morphology in the retina. Glia 2016;64:2005-2024.

-49 Syeda S, Patel AK, Lee T, Hackam AS: Reduced photoreceptor death and improved retinal function during retinal degeneration in mice lacking innate immunity adaptor protein MyD88. Exp Neurol 2015;267:1-12.

50 Sancho-Pelluz J, Wunderlich KA, Rauch U, Romero FJ, van Veen T, Limb GA, Crocker PR, Perez MT: Sialoadhesin expression in intact degenerating retinas and following transplantation. Invest Ophthalmol Vis Sci 2008;49:5602-5610.

51 Vakilian A, Khorramdelazad H, Heidari P, Sheikh Rezaei Z, Hassanshahi G: CCL2/CCR2 signaling pathway in glioblastoma multiforme. Neurochem Int 2017;103:1-7.

52 Yadav A, Saini V, Arora S: MCP-1: chemoattractant with a role beyond immunity: a review. Clin Chim Acta 2010;411:1570-1579.

53 Chen M, Zhao J, Luo C, Pandi SP, Penalva RG, Fitzgerald DC, Xu H: Para-inflammation-mediated retinal recruitment of bone marrow-derived myeloid cells following whole-body irradiation is CCL2 dependent. Glia 2012;60:833-842.

54 Rangasamy S, McGuire PG, Franco Nitta C, Monickaraj F, Oruganti SR, Das A: Chemokine mediated monocyte trafficking into the retina: role of inflammation in alteration of the blood-retinal barrier in diabetic retinopathy. PLoS One 2014;9:e108508.

55 Rustenhoven J, Aalderink M, Scotter EL, Oldfield RL, Bergin PS, Mee EW, Graham ES, Faull RL, Curtis MA, Park TI, Dragunow M: TGF-beta1 regulates human brain pericyte inflammatory processes involved in neurovasculature function. J Neuroinflammation 2016;13:37.

-56 Puthussery T, Fletcher E: Extracellular ATP induces retinal photoreceptor apoptosis through activation of purinoceptors in rodents. J Comp Neurol 2009;513:430-440.

57 Byrne LC, Dalkara D, Luna G, Fisher SK, Clerin E, Sahel JA, Leveillard T, Flannery JG: Viral-mediated RdCVF and RdCVFL expression protects cone and rod photoreceptors in retinal degeneration. J Clin Invest 2015;125:105-116.

-58 Elachouri G, Lee-Rivera I, Clerin E, Argentini M, Fridlich R, Blond F, Ferracane V, Yang Y, Raffelsberger W, Wan J, Bennett J, Sahel JA, Zack DJ, Leveillard T: Thioredoxin rod-derived cone viability factor protects against photooxidative retinal damage. Free Radic Biol Med 2015;81:22-29.

59 Mei X, Chaffiol A, Kole C, Yang Y, Millet-Puel G, Clerin E, Ait-Ali N, Bennett J, Dalkara D, Sahel JA, Duebel J, Leveillard T: The thioredoxin encoded by the rod-derived cone viability factor gene protects cone photoreceptors against oxidative stress. Antioxid Redox Signal 2016;24:909-923.

-60 Mirza M, Volz C, Karlstetter M, Langiu M, Somogyi A, Ruonala MO, Tamm ER, Jagle H, Langmann T: Progressive retinal degeneration and glial activation in the CLN6 (nclf) mouse model of neuronal ceroid lipofuscinosis: a beneficial effect of DHA and curcumin supplementation. PLoS One 2013;8:e75963.

61 Xie P, Zhang W, Yuan S, Chen Z, Yang Q, Yuan D, Wang F, Liu Q: Suppression of experimental choroidal neovascularization by curcumin in mice. PLoS One 2012;7:e53329. 


\section{Cellular Physiology Cell Physiol Biochem 2017;44:479-493

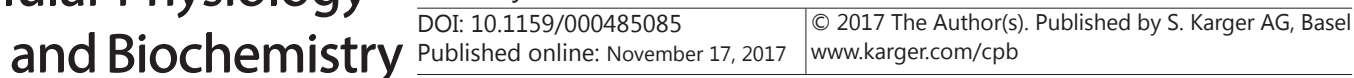

Wang et al.: Curcumin Delays Retinal Degeneration

62 Clermont A, Murugesan N, Zhou Q, Kita T, Robson PA, Rushbrooke LJ, Evans DM, Aiello LP, Feener EP: Plasma kallikrein mediates vascular endothelial growth factor-induced retinal dysfunction and thickening. Invest Ophthalmol Vis Sci 2016;57:2390-2399.

-63 Falavarjani KG, Golabi S, Modarres M: Intravitreal injection of methotrexate in persistent diabetic macular edema: a 6-month follow-up study. Graefes Arch Clin Exp Ophthalmol 2016;254:2159-2164.

-64 Hombrebueno JR, Ali IH, Xu H, Chen M: Sustained intraocular VEGF neutralization results in retinal neurodegeneration in the Ins2(Akita) diabetic mouse. Sci Rep 2015;5:18316.

65 Pacella F, Ferraresi AF, Turchetti P, Lenzi T, Giustolisi R, Bottone A, Fameli V, Romano MR, Pacella E: Intravitreal injection of Ozurdex((R)) implant in patients with persistent diabetic macular edema, with sixmonth follow-up. Ophthalmol Eye Dis 2016;8:11-16.

66 Zhang S, Zhai G, Shi W, Wang Y, Zhu L, Dai Y, Chen C: Pigment epithelium-derived factor inhibits oxygeninduced retinal neovascularization in a murine model. Fetal Pediatr Pathol 2016;35:173-85.

67 Maria DN, Mishra SR, Wang L, Abd-Elgawad AH, Soliman OA, El-Dahan MS, Jablonski MM: Water-soluble complex of curcumin with cyclodextrins: enhanced physical properties for ocular drug delivery. Curr Drug Deliv 2017;14: 875 - 886

68 Ayadi F, Bayer IS, Marras S, Athanassiou A: Synthesis of water dispersed nanoparticles from different polysaccharides and their application in drug release. Carbohydr Polym 2016;136:282-291.

69 Charoensuk L, Pinlaor P, Wanichwecharungruang S, Intuyod K, Vaeteewoottacharn K, Chaidee A, Yongvanit P, Pairojkul C, Suwannateep N, Pinlaor S: Nanoencapsulated curcumin and praziquantel treatment reduces periductal fibrosis and attenuates bile canalicular abnormalities in Opisthorchis viverrini-infected hamsters. Nanomedicine 2016;12:21-32.

-70 Ding L, Li J, Huang R, Liu Z, Li C, Yao S, Wang J, Qi D, Li N, Pi J: Salvianolic acid B protects against myocardial damage caused by nanocarrier TiO2; and synergistic anti-breast carcinoma effect with curcumin via codelivery system of folic acid-targeted and polyethylene glycol-modified TiO2 nanoparticles. Int J Nanomedicine 2016;11:5709-5727.

-71 Jyoti K, Pandey RS, Kush P, Kaushik D, Jain UK, Madan J: Inhalable bioresponsive chitosan microspheres of doxorubicin and soluble curcumin augmented drug delivery in lung cancer cells. Int J Biol Macromol 2017;98:50-58.

72 Mapoung S, Pitchakarn P, Yodkeeree S, Ovatlarnporn C, Sakorn N, Limtrakul P: Chemosensitizing effects of synthetic curcumin analogs on human multi-drug resistance leukemic cells. Chem Biol Interact 2016;244:140-148.

73 Zhang Y, Zhou J, Yang C, Wang W, Chu L, Huang F, Liu Q, Deng L, Kong D, Liu J, Liu J: Folic acid-targeted disulfide-based cross-linking micelle for enhanced drug encapsulation stability and site-specific drug delivery against tumors. Int J Nanomedicine 2016;11:1119-1130.

74 Zheng S, Gao X, Liu X, Yu T, Zheng T, Wang Y, You C: Biodegradable micelles enhance the antiglioma activity of curcumin in vitro and in vivo. Int J Nanomedicine 2016;11:2721-2736. 